
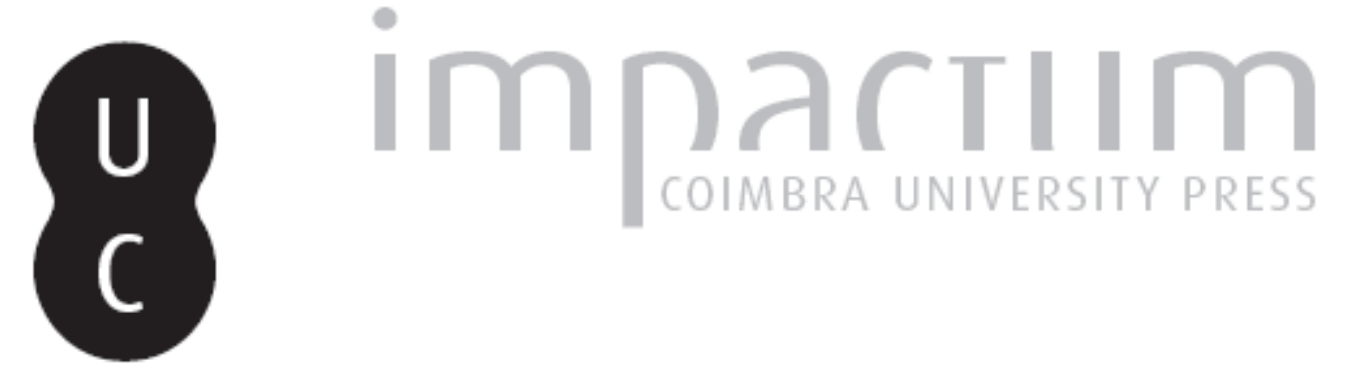

\title{
GeoNeoLogical novel and other hybrimedia experiments: or how to use hybrid methods such as Hybrid Discourse Analysis (HDA) within a knowledge base
}

\author{
Autor(es): $\quad$ Andrade, Pedro
}

Publicado por: Centro de Literatura Portuguesa; Imprensa da Universidade de Coimbra

URL persistente:

URI:http://hdl.handle.net/10316.2/39102

DOI:

DOI:http://dx.doi.org/10.14195/2182-8830_4-2_8

Accessed : $\quad$ 26-Apr-2023 07:24:30

A navegação consulta e descarregamento dos títulos inseridos nas Bibliotecas Digitais UC Digitalis, UC Pombalina e UC Impactum, pressupõem a aceitação plena e sem reservas dos Termos e Condições de Uso destas Bibliotecas Digitais, disponíveis em https://digitalis.uc.pt/pt-pt/termos.

Conforme exposto nos referidos Termos e Condições de Uso, o descarregamento de títulos de acesso restrito requer uma licença válida de autorização devendo o utilizador aceder ao(s) documento(s) a partir de um endereço de IP da instituição detentora da supramencionada licença.

Ao utilizador é apenas permitido o descarregamento para uso pessoal, pelo que o emprego do(s) título(s) descarregado(s) para outro fim, designadamente comercial, carece de autorização do respetivo autor ou editor da obra.

Na medida em que todas as obras da UC Digitalis se encontram protegidas pelo Código do Direito de Autor e Direitos Conexos e demais legislação aplicável, toda a cópia, parcial ou total, deste documento, nos casos em que é legalmente admitida, deverá conter ou fazer-se acompanhar por este aviso.

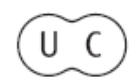



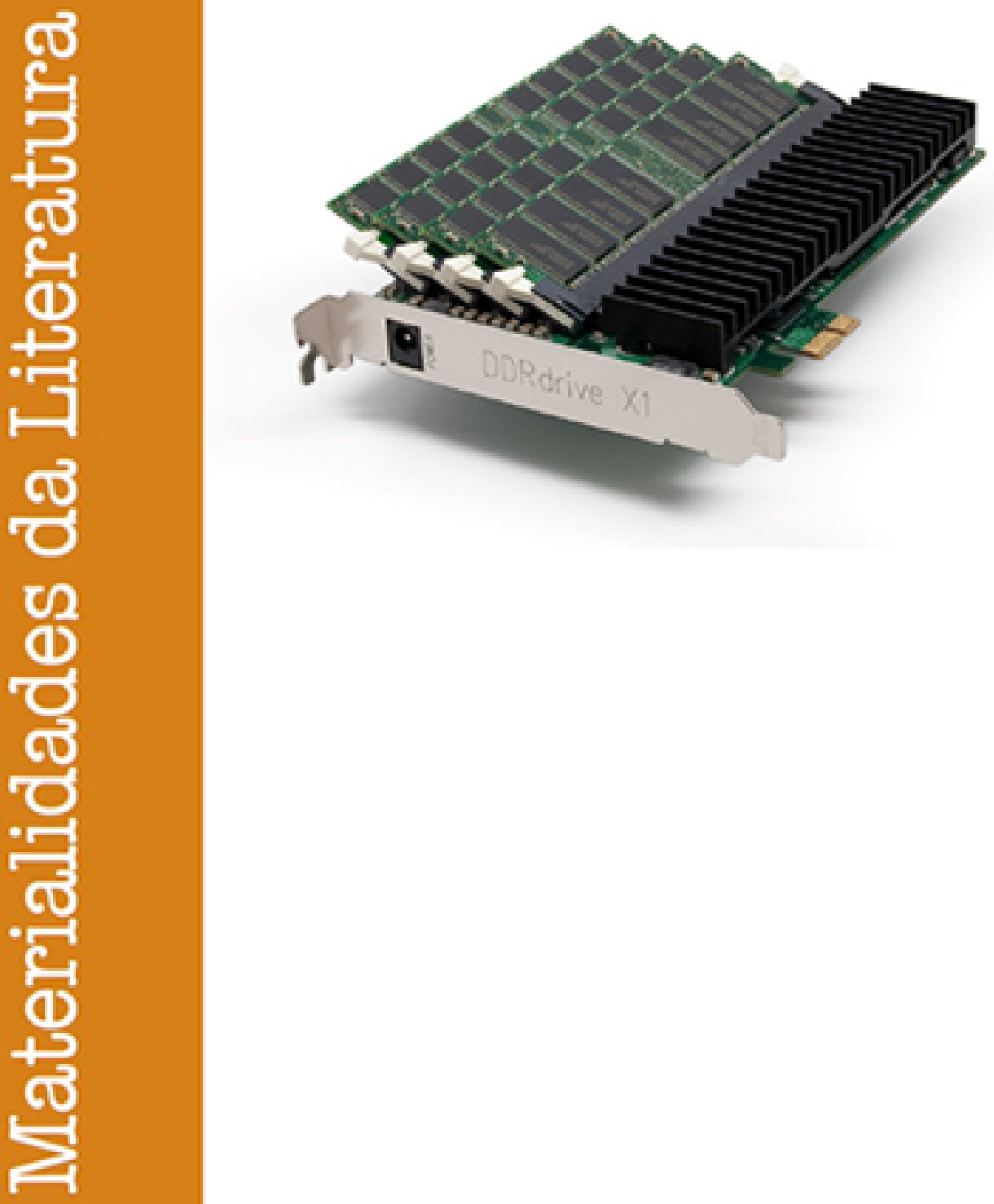

Vol. 4.2 (2016) ISSN 2182-8830

'Estudos Literários Digitais 2'

Manuel Portela e António Rito Silva (orgs.) 


\title{
GeoNeoLogical Novel and other Hybrimedia Experiments: or how to use Hybrid Methods such as Hybrid Discourse Analysis (HDA) within a Knowledge Base PeDRo ANDRADE
}

\author{
University of Minho
}

\begin{abstract}
In this essay I will present some results of the project Public Communication of Art, which developed a seminal theory and methodology intended to cope with hybridity and new media literacy in our globalized and inter/transcultural world. Some of the methods used blend vision with touch and are called 'hybrid methods' or 'hybrimethods'. Examples of these are, for instance, a Multitouch Interactive Table, a Multitouch Questionnaire, Trichotomies Game and GeoNeoLogic Novel, this last one being a hybrid novel activated by fusion of vision, touch and GPS coordinates. Another hybrimethod is a sort of discursive analysis, named Hybrid Discourse Analysis (HDA), which uses 'semantic-logical networks' organized by concepts and 'relation-concepts'. HDA is here articulated with Critical Sociology and applied to the analysis of a text on Magic Realism, which is also a hybrid genre within the social field of literature. Keywords: GeoNeoLogic Novel; hybrimethods; Hybrid Discourse Analysis (HDA); Magic Realism; semantic-logical networks; Alphabet of Interconceptual Relations.
\end{abstract}

\begin{abstract}
Resumo
Este ensaio apresenta alguns resultados do projeto Comunicação Pública da Arte, que desenvolveu uma teoria e uma metodologia seminais, destinadas a lidar com o hibridismo e a literacia dos novos média no seio do nosso mundo globalizado e inter/ transcultural. Alguns destes métodos hibridizam a visão com o toque, e são designados 'métodos híbridos' ou 'hibrimétodos'. Exemplos incluem uma Mesa Interativa Multitoque, um Questionário Multitoque, o Jogo das Tricotomias e a Novela GeoNeoLógica, uma novela híbrida ativada pela fusão da visão, tato e coordenadas GPS. Outro hibrimétodo é um tipo de análise discursiva designada Análise Híbrida de Discurso (AHD), que utiliza 'redes semânticas-lógicas' organizadas por conceitos e 'relações-conceitos'. A AHD é aqui articulada com a Sociologia Crítica e aplicada à análise de um texto sobre o Realismo Mágico, que se carateriza igualmente enquanto género híbrido no seio do campo social da literatura. Palavras-chave: Novela GeooNeoLógica; hibrimétodos; Análise Híbrida de Discurso (AHD); Realismo Mágico; redes semânticas-lógicas; Alfabeto de Relações Interconceptuais.
\end{abstract}




\section{Introduction: a critical and bybrid discussion}

$\mathbf{M}$ ultiple epistemological, theoretical and methodological debates are currently taking place, in order to cope with the present crisis within our contemporary globalized, post-colonial and inter/transcultural world. In the area of social and human sciences, a growing community of authors is trying to understand, in particular, how phenomena like communication, discourse and language can be related to such a conjuncture. ${ }^{1}$ More recent arguments focus on the articulation between digital practices, as the divide between online and offline communication (Tagg, 2015), and digital discourse analysis. ${ }^{2}$

In this perspective, the role of language and its analysis is perceived as central within the digital discourse vehiculated by digital communicative contexts such as blogging, mobile phones, gaming, and social networks (Thurlow, 2011). An example of these approaches is the analysis of the digital nature of literary texts, regarding characterization, diction, style and profound interpretation of words in the literary text and its context. This is done through statistical but also qualitative methods for the analysis of natural language corpora (Hoover, 2014).

Other authors go a step further: they insist on the relevance of arts and literature as sensitive and sometimes sensual instruments, modes and methods of interpretation within research projects, complementary to scientific and 'objective' methodology and technological practices (Leavy, 2009). In this new epistemological exercise, the role of digital writing is crucial. ${ }^{3} \mathrm{On}$ the pragmatic side, not only students, but teachers and researchers as well, should pay more attention to the way they write and the style they use in cyberspace and cybertime. ${ }^{4}$ Since 2008 , one year after the launch of the iPhone, we have used this device to construct the GeoNeoLogical Novel, which was first presented in 2009 at the event Arte Midia, organized by the Universi-

${ }^{1}$ Discussions on Discourse Analysis undertaken by researchers may be central to clarifying this situation. A recent book (Gee, 2013) gathers major contributions useful for researchers in the field of Communication and Cultural Studies and within other social sciences and Humanities. It covers the main trends of this vast area and their applications to concrete social contexts, such as Critical Discourse Analysis, Multimodal Discourse Analysis, Multimedia Discourse Analysis, and Inter/Transcultural Communication.

2 In particular, the need to change our analytical habits emerges as new technologies are not only irreversibly transforming the way we act, but the way we do theory and use methodology as well, e.g. in the cases of conversation analysis or geosemiotics (Jones, 2015).

${ }^{3}$ Digital storytelling raises new questions within narrative theory itself. Digital subgenres which were never seen before are emerging, in close connection with cyberspace's social and cultural contexts (Page, 2011).

${ }^{4}$ Brian Caroll (2014) shows how to write effectively in digital social spaces using storytelling and multi-directional communication, among other strategies. This author states that one of the most promising ways to write digitally, fiction or non-fiction, is the use of mobile devices and geo-mapped media ecosystems. 
ty of São Paulo. Some details concerning this experimental novel, which uses a GPS system to relate characters to the novel's plot, are given below.

The very nature of science is changing. In her remarkable study, Valerie Hanson (2015) invites us to think visually while doing science, and uses rhetoric, extensively and intensively. She says that we can see by touching and touch by seeing, e.g. with the help of new techno-sciences like nanotechnology, which use tools allowing a user to literally see touch. Between 2006 and 2010, touch and vision were fusioned within sociological, artistic and literary hybrimethods conceived by the 'hybrid team' (i.e. including sociologists, programmers and designers) of the project Public Communication of Art, as explained below.

In a word, science, technology and arts are blending, in the very process and at a moment when these types of knowledge interpret the social fabric. In fact, bybridity has been a stimulating idea in the last decades in the field of critical sociology and anthropology (Canclini, 2005). The same happened in the literary social field, e.g. in the case of critical interpreters of literature (Bakhtin, 1985) and critical literary postures such as the Magic Realism cultural movement, including writers such as Garcia Marquez (2006), Isabel Allende, Salman Rushdie or Milan Kundera.

In such a context, it seems urgent that social and human sciences develop more critical and hybrid conceptualizations and methodologies, in close partnership with other types of knowledge (Andrade, 2014). To understand some of these social processes/discourses and the corresponding social sciences and artistic reformulations, in this essay we will discuss a specific approach articulating critical sociology with hybrid theory and methodology, which is named Hybrid Discourse Analysis (HDA).

This approach may be defined as a critical and hybrid way of undertaking discourse analysis through fusions between the different natures of things, while analyzing a given corpus of social data. HDA hybrid nature may be understood as:

(a) an articulation between critical social/human sciences and arts/ literature;

(b) a hybridization of methodological approaches, for instance, both quantitative and qualitative procedures;

(c) a blending between traditional and experimental methods;

(d) a dialogue between pre-digital and digital media;

(e) a dialectics of, on one hand, 'classical' media relationships like hypermedia and, on the other hand, emerging digital combinations of media, such as bybrimedia. This last concept refers to the hybridization among media/literacies of different nature, for instance visual and touch through digital devices, as we will illustrate in this essay.

HDA could be a reliable method to achieve the following objectives/results: first, to reflect on society in general, that is, on the macro social structures such as culture, communication, information; second, to give evi- 
dence of particular micro practices and significant socio-cultural agents. In short, through the several critical and hybrid methods presented below, social structures and practices can be observed in their spatial and temporal contexts, where meaning is circulating, activated by common people.

Through the use of such strategy, social structures and practices may be commented upon and criticized not only by researchers but by nonspecialists as well, by means of activities within their everyday spatial and temporal contexts, e.g. using iPhones, GPS, and other devices and software applications. In fact, visual/touch devices may be considered precious instruments for discursive analysis on institutional modes of communication, by witnessing and clarifying social and cultural realities, in a unique and sometimes surprising way. At the same time, they must also be analysed in a more substantive way, that is, as vehicles of specific discourses and counterdiscourses.

\section{Hybrid Discourse Analysis and the Web}

First of all, it is necessary to contextualize the social arena where we may apply such methodology. According to Manuel Castells (2000), these days we live in a network society. Nevertheless, this society paradigm needs to be discussed more in-depth and sometimes reformulated, as network society itself is changing. In fact, during the last decade of the 20th century-at the so-called Web 1.0 -, users mainly read information and did little writing. Since the first decade of the third millennium, the Web 2.0 has become a new paradigm of communication. It is also and often designated reading / writing internet, as the user, besides reading information, is capable of producing and exchanging multiple types of content, in a stronger active and intersubjective posture than $\mathrm{s} /$ he did in the former internet communication regime. For example, in a blog, a post written by a seminal user may not only be read, but also be answered through a critical comment by a second user. Deborah Tannen (2013) puts forward an understanding of the 'participatory spectacle' in Web 2.0, and of its influence in everyday life, education and reconstruction of meaning.

Nowadays, the so-called $W e b 3.0$ is emerging as a new style of reception and production of information, knowledge and meaning. It is often referred to as Semantic $W e b$, because its main aim is to construct sites and social webs whose model of semantic meaning and knowledge (concepts, logical relations, etc.) is explicit, especially the meaningful relationships among pieces of information. For example, a web page named 'Discourse Analysis' may be related, through a hierarchical link, to another with the title 'Grounded Theory', which is a more specific concept, i.e. a style of Discourse Analysis. This relationship may be indicated in a label saying: 'Discourse Analysis' is the general term of 'Grounded Theory'. And both concepts may be defined in a 
glossary. In other words, within a Web 3.0 site or page, the semantic meanings of both its content and the relationships among its parts are explained.

Aiming to apply such considerations, a financed research project developed between 2006 and 2011 at the University of Lisbon titled "Public Communication of Art: the case of local/global art museums" undertook a critique of museum's organization, communication strategies and discourses regarding multiple and evolving audience segments. Besides studying the classical audience profiles (such as families, students/teachers and tourists), it is also crucial to consider other social actors, such as immigrants, people with special needs and pensioners. In fact, according to Crimp (1995), present museum paradigms are no longer legitimated.

In particular, the "Public Communication of Art Project", inspired by Web 2.0 and Web 3.0 technologies, and by the corresponding Semantic and Logical Turn, recently developed a specific Semantic-Logical Methodology directed at museum audiences within the context of networked societies, in particular for reading and writing social texts, images, video, 3D and other media (Andrade et al., 2010; Andrade, 2016). This has been undertaken within a critical Semantic-Logical Sociology perspective and using Hybrid Discourse Analysis procedures, such as Hybrid Methods, a methodology that, besides articulating several social network types (Andrade, 2010b), hybridizes vision and touch (Idem, 2011a). The present essay briefly discusses some of the theoretical and empirical outcomes of this project, particularly those that introduce the above mentioned Semantic-Logical and Hybrid approaches.

\section{Semantic-Logical Sociology and Hybrid (Visual-Touch) Methods}

Hybridity has several ways or modes of manifesting itself in the social arena:

(a) in everyday life, through the fusion of social physical life with social virtual life;

(b) inside internet and digital worlds, by mixing media through mashups (web pages or apps that blend content from diverse sources in a single interface) or modding (hardware or software modified from the original design) or fusioning vision with touch modes for apprehension of reality through digital devices;

(c) by articulating different forms of knowledge, e.g. the hybridization of science with arts;

(d) in knowledge, by blending scholarly/research concepts and professional terms with popular concepts;

(e) through social agents who may act both as experts and common citizens;

(f) inside literary contexts, through citizens who may switch to a novel character, inside critical bybrid novels (as in the GeoNeoLogical Novel, see below); etc. 
To interpret such hybridized complexity in our inter/transcultural society, a critical Semantic-Logical Sociology constitutes a sociological strategy that, among other things, uses hybrid methods or hybrimethods. Such hybrimethods may use innovative visual and touch devices to study society, like those constructed in the above-mentioned project "Public Communication of Art". Specifically, this project has a sociological level that is subject to methodological hybridization. In the first level, art audiences were studied through a survey at a museum in Lisbon, through more classical methods, such as a questionnaire, interviews and direct observation. In the second level, the project developed some custom hybrimedia Semantic and Logical methods, such as:

Hybrimethod 1: a Multitouch Interactive Table where museum visitors can get acquainted with art works, through vision and touch; make comments on them and their semantic meaning with tags and texts; or establish logical and visual relationships among these art works through visual

webs (see Fig. 1).

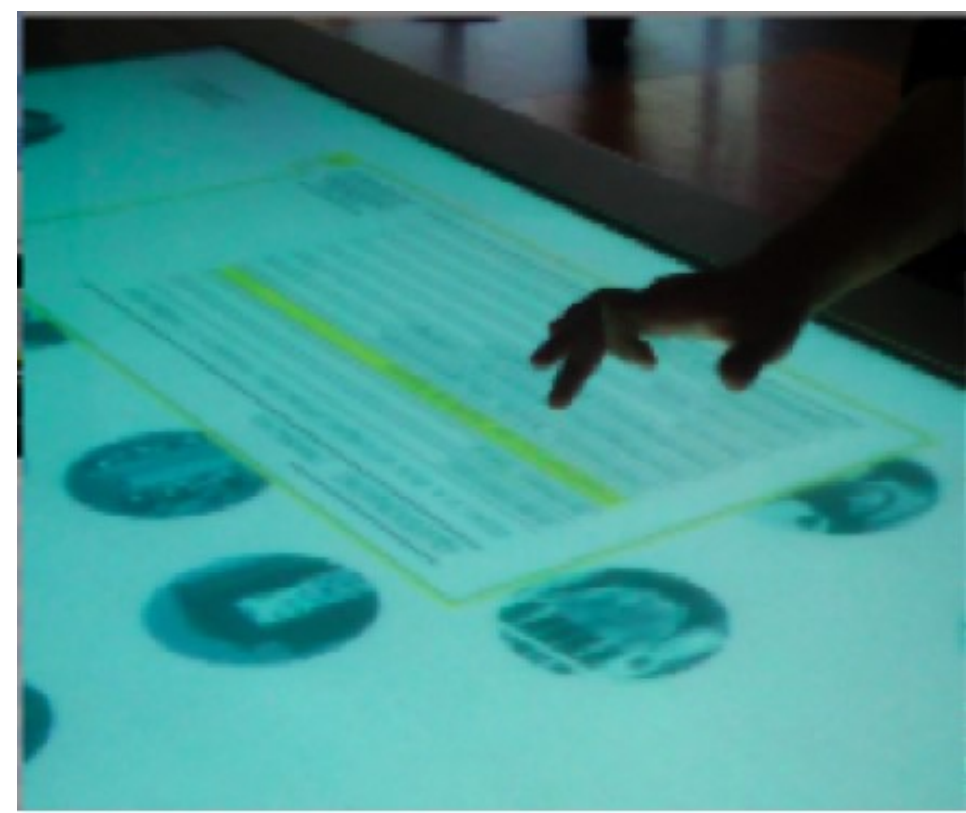

Figure 1. Hybrimethods 1 and 2: a Multi-touch Interactive Table including a Multitouch Questionnaire for visitors use.

Hybrimethod 2: in this table, the project also constructed a Multitouch Questionnaire where audiences answered by seeing questions and images, and touching options for responding. 
Hybrimethod 3: art audiences could also play a visual-touch game named the Trichotomies Game, where they had to find logical relationships between 3 artworks, in order to win the game, using hybrid methods (that is, visual and touch procedures). A trichotomy is a semantic web that relates 3 ideas or concepts (Fig. 2).

Hybrimethod 4: a Visual Novel for making Visual Critical Sociology used semantic-logical and visual-touch tasks (Fig. 3). The aim was to use literature to understand social discourses, in the context of Web 2.0 and Web 3.0. To our knowledge, this is the first novel to be publicized applying Web 3.0 technologies (see, at References section: Andrade, 2001c, and Social Semantic Site Web 3 Novel).

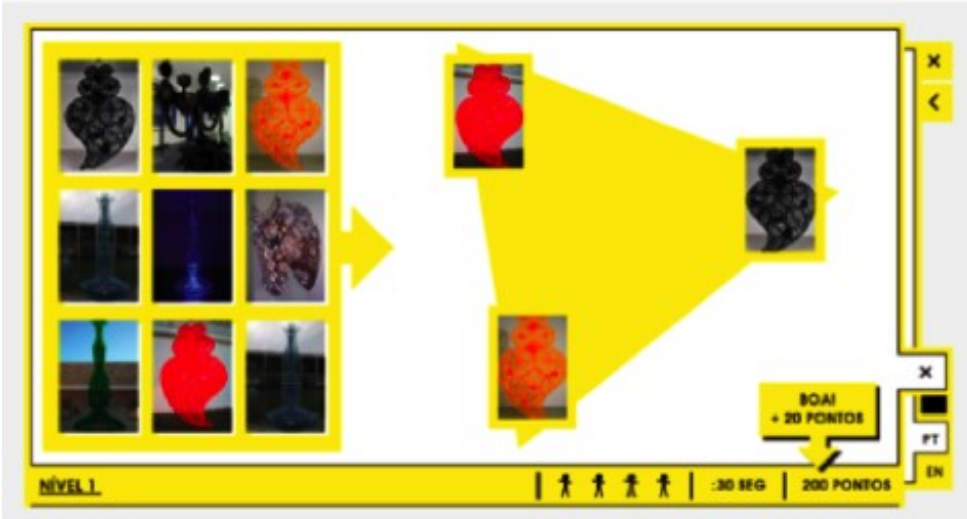

Figure 2. Hybrimethod 3: Trichotomies Game, a Hybrimethod fusioning vision and touch.

Its name is GeoNeoLogical Novel No.1, which means a socio-semantic literary hybrimedia work that examines the social fabric and its discourses, through the deconstruction/reconstruction of a social plot based on deixis. This term, deixis, can be perceived as a conceptual constellation originating in Greek philosophy, which articulates space, time, and logos. The meaning of logos may be 'language', 'reason' or the discourse produced by social subjects like institutions or citizens. The discursive subjects act as hybrid-characters emerging from intercultural daily temporalities/spatialities of the global/local city. GeoNeoLogical Novel No.1 users activate an interface where time and space of scenes are represented by photos (at center), GPS coordinates (at top right) and maps (at the right), which show where and when scenes occur. The text on the left includes the following manifestations of logos: (a) a database of the novel's authors; (b) social actors that work as fictional characters; (c) narration; and (d) dialogue. 


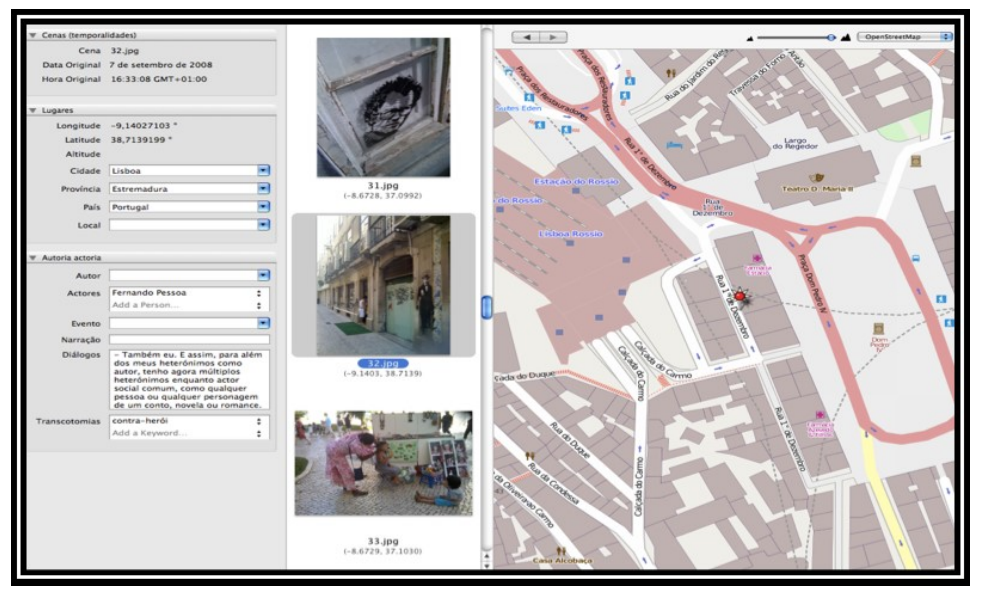

Figure 3. Hybrimethod 4: GeoNeoLogical Novel No.1, the first Web 3.0 novel.

Therefore, this critical sociological novel, in addition to its artistic purposes, also aims to serve as a sociological hermeneutic device, i.e. a singular kind of digital method to understand 'real' social worlds, as well as the virtual worlds and metaverses or 3D worlds, by mobilizing textual, visual and tactile social instruments.

In this way, not just social meaning, but also sociological meaning may circulate simultaneously among both Social Sciences experts and nonspecialists. All social actor participating in the novel may act, in some manner: (a) as bybrid characters in the novel when they speak or narrate their inter/transcultural and intermediating everyday lives, but also: (b) as sociological actors, that is, a sort of lay researchers.

The meaning of the concept 'lay researchers' within GeoNeoLogical Novel is the following: social actors using new media may build mobile interactive biographies, by taking and sharing photos and comments within their everyday life. They also produce 'folksonomies', that is, non-specialist concepts (concepts not necessarily produced within an academic, research or professional context) or tags defined and included by users inside blogs, social networks, etc. In effect, our society is becoming a Research Society, where everybody aledgely may both search (using Google, etc.) and research, using common technological and mobile devices (Andrade, 2008; 2011b).

\section{Wikipedia's Hybrid hermeneutics}

Hybrimethod 5: Hybrid Discourse Analysis (HDA) is another example of a hybrid methodology developed within the project. As stated in the introduction, this analytical and interpretative tactic serves, among other objectives, to pursue the content/discourse analysis of hybrid social processes. One such phenomenon is the literary and artistic movement called "Magic 
Realism". Its authors developed works that depict not only South American social reality, but also our globalized intercultural and hybridized planet. To understand such social processes and the accounts on them produced by authors of Magic Realism, this essay will interpret some aspects of the discourse underlying the digital encyclopedia Wikipedia's article entitled "Magic Realism", in its English language version (see Fig. 4 and this webpage's address in the References). A first reading of this webpage was made on the $20^{\text {th }}$ of September, 2012, and currently another analysis is in progress.

For analytical purposes, the article was subdivided into 5,922 semanticsyntactic units. In other words, this text was not just sub-divided by syntactic parts, but also by units that already made some sense during the first steps of interpretation. Such previous meaning was progressively deepened during the progression of the analysis.

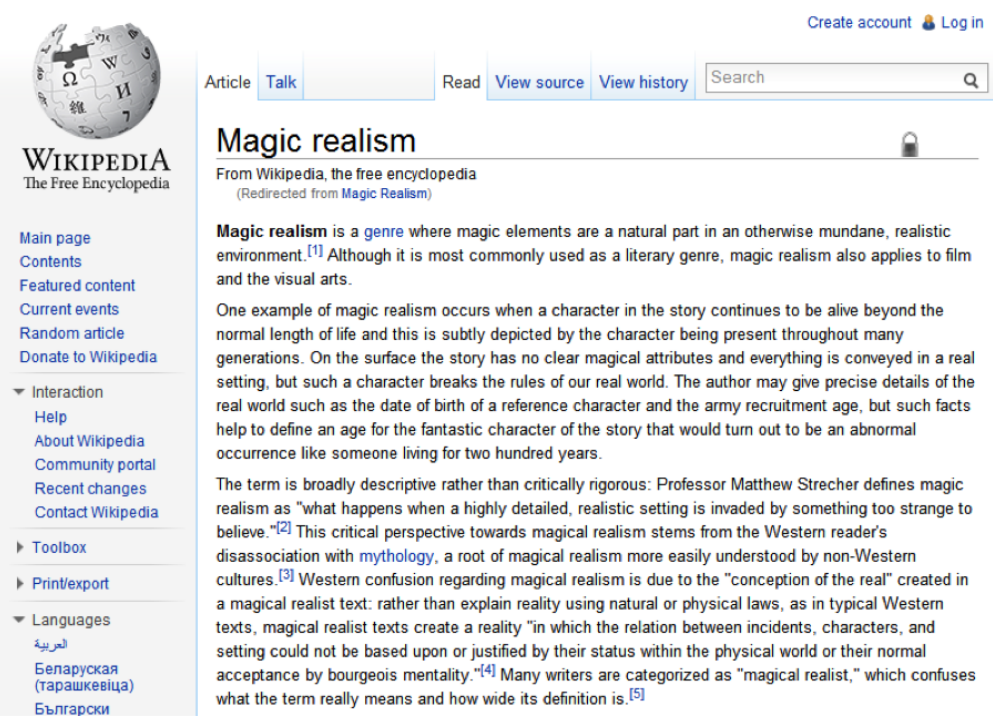

Figure 4. Hybrimethod 5: Hybrid Discourse Analysis (HDA) on article "Magic realism" in Wikipedia: this figure shows the 3 paragraphs that define its first social semantic field.

\subsection{A Sociological Knowledge Base on Literary Discourse}

The project built a Sociological Knowledge Base, which is briefly presented here through some results included in just one of its parts, the section relating to literature, named Knowledge Base on Literary Discourse. A Knowledge Base gathers meanings represented by concepts and logical relationships, within a specific knowledge area divided into semantic fields.

For such aim, let us look firstly for occurrences of the main keywords in this corpus, and organize them under socially pertinent semantic fields. Fig. 5 shows only the notions and their respective frequencies in an Arts \& Culture 
semantic field that includes 569 occurrences in the text, distributed within the respective keywords. We defined other semantic fields considered relevant to analyzing Magic Realism, for instance a collection of Locations and Time connotations. However, please note that here the scope is just to present some selected examples of Hybrid Methodologies' relevance, and mainly its application to a sketch of HDA, a methodology that is emerging.

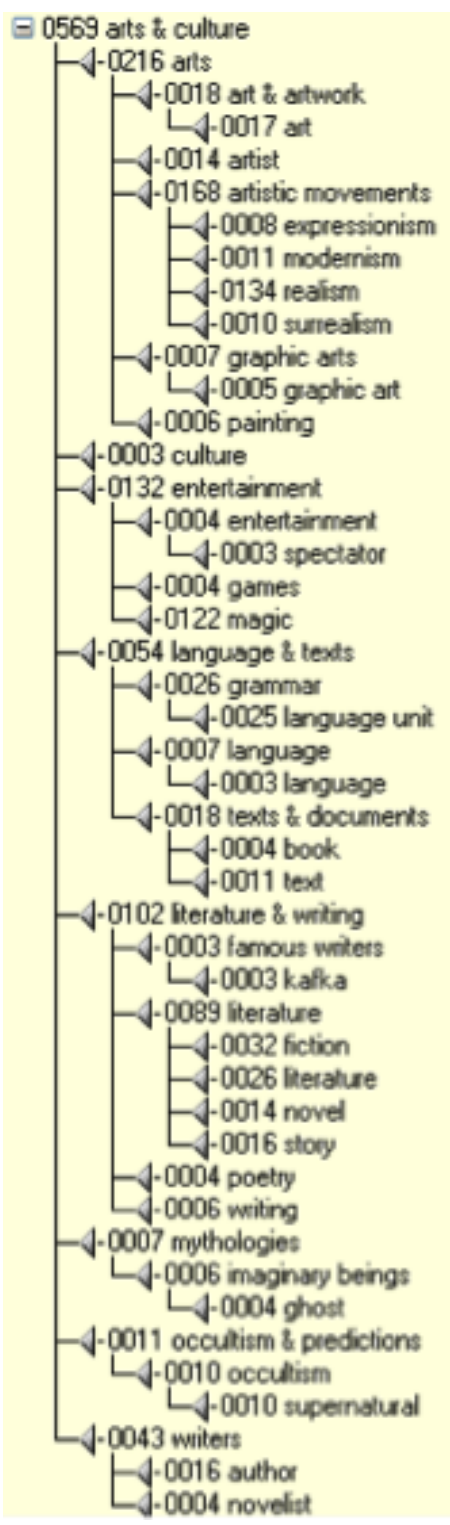

Figure 5. Sociological Knowledge Base: Literary Discourse: Social semantic field 'Arts\&Culture'. 
Furthermore, it is important to underline that often it is not enough to undertake a hermeneutic quest based only on the leading concepts isolated from their relations. Thus, HDA uses a specific type of networks, semanticlogical networks, to represent both these instruments of interpretation, concepts and relations. Better said, such webs were constructed to organize the semantics of key concepts linked to the logic of their main relations, within the internet page selected: this analysis will focus primarily on the meaning of concepts, but also on the types of both logical and argumentative connections that articulate them. Furthermore, such qualitative approach was hybridized, partly, with a quantitative approach.

\subsection{Semantic-Logical Networks}

A good practice for conducting a Hybrid Discourse Analysis is to articulate and sometimes hybridize ideas in several ways, in order to extract multiples social meanings and not just the more evident ones. Concretely, this can be done not only through analysis of concepts and their relations in a given corpus, but also through several social and sociological network configurations. The derived knowledge may hopefully allow more and deeper discourse interpretations.

Consider a general semantic class named Artistic Movements, where Magic Realism may be included (Fig. 5). That class has 168 mentions (the most frequent occurrences within a class) across all the semantic-syntactic units of the webpage.

A semantic-logical network may be extracted, showing the main concepts related with the idea of Artistic Movements (Fig. 6). Such concepts are represented in the image by spheres, and the corresponding semantic meanings are connected through logical relationships, showed as lines.

(a) Qualitative approach.

Observe the actant/acted ratio, visible at the horizontal $\mathrm{X}$-axis. In other words, the notions to the left, noted in blue, mean antecedent/ precedent/previous words in the sentences, while those to the right, in green, represent the consequent/following/resulting notions, within the total number $(5,922)$ of the article's propositions.

(b) Quantitative approach.

The vertical $\mathrm{Y}$-axis locates the relative concentration of relations for each concept, at the top the strongest and, at the bottom, the weakest. A dotted line indicates an infrequent link. A solid line connotes a frequent association. 


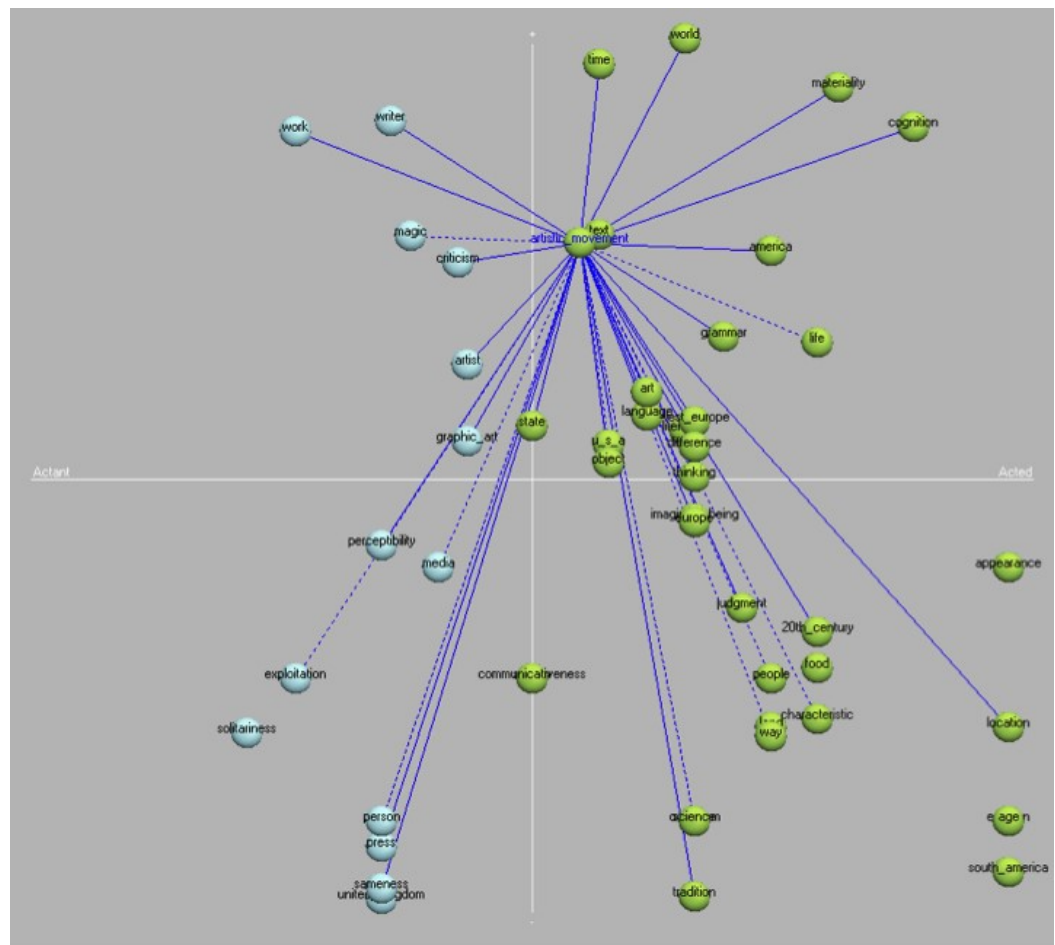

Figure 6. Artistic Movements semantic-logical network.

A semantic-logical network may be extracted, showing the main concepts related with the idea of Artistic Movements (Fig. 6). Such concepts are represented in the image by spheres, and the corresponding semantic meanings are connected through logical relationships, showed as lines.

(a) Qualitative approach.

Observe the actant/acted ratio, visible at the horizontal X-axis. In other words, the notions to the left, noted in blue, mean antecedent/precedent/previous words in the sentences, while those to the right, in green, represent the consequent/following/resulting notions, within the total number $(5,922)$ of the article's propositions.

(b) Quantitative approach.

The vertical $\mathrm{Y}$-axis locates the relative concentration of relations for each concept, at the top the strongest and, at the bottom, the weakest. A dotted line indicates an infrequent link. A solid line connotes a frequent association.

As for the idea of Magic Realism itself, Fig. 7 shows another way of analyzing relationships among concepts: 
(c) Qualitative approach.

Regularities are expressed by qualitative significant articulations among pairs of concepts (that is, through antecedent and consequent concepts) within the articles' sentences. On the left are the precedent concepts, on the right its successors.

(d) Quantitative approach.

Such semantic (qualitative) articulations are ordered (quantitatively) from the higher frequencies on top to the lower occurrences at the bottom. For example, 'surrealism' occurs twice as an antecedent concept and once as a consequent concept.

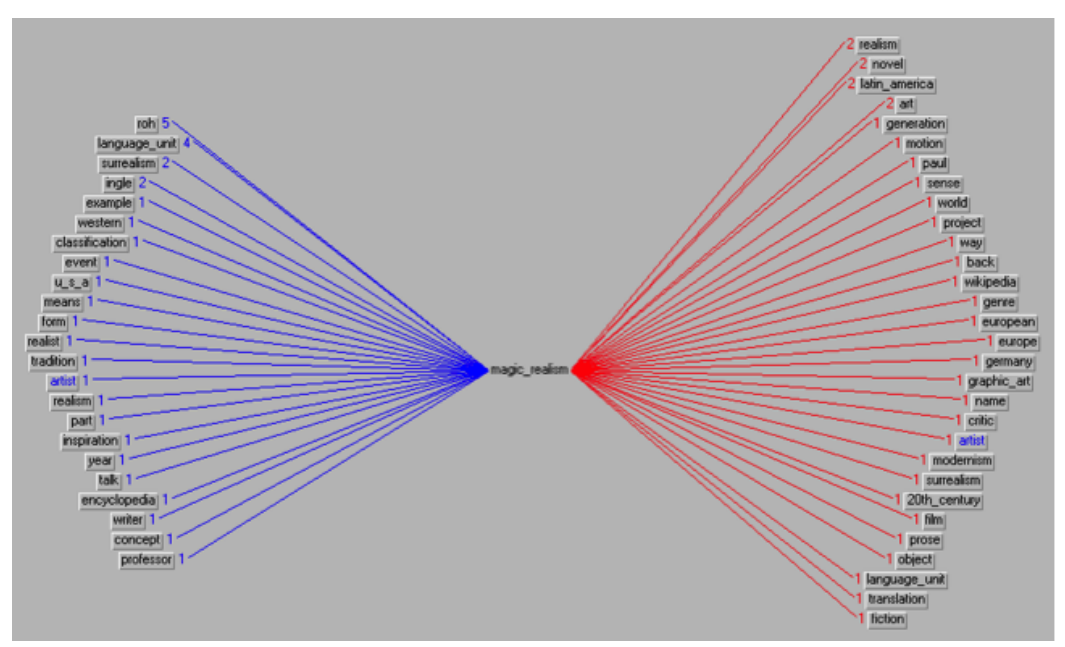

Figure 7. 'Magic Realism' semantic-logical network.

It is possible to try a more profound analysis, this time involving not just one main notion, but two clusters, each one associated to a main concept, and even three concepts connected directly or indirectly, within the context of Magical Realism (the main idea in this Wikipedia article). Such constellation of 3 concepts was named "trichotomy". For instance, in Fig. 8, three main ideas discussed in the text used as corpus, were linked in 2 stages:

Firstly, the concept 'reader' was connected with the notion of social 'world'. This is represented by the lines (i.e. relations) in blue. Here are some sentences in the article where these notions occur (the correspondent indicators are noted in italic):

"With its multiple realities and specific reference to the reader's world, it explores the impact fiction has on reality, reality on fiction and the read$e r^{2} s$ role in between;"

"where the textual world enters into the reader's (our) world." 
"The important idea in defining the marvelous is that readers understand that this fictional world is different from the world where they live."

"In this way, a realist narrative acts as framework by which the reader constructs a world using the raw materials of life."

Secondly, both ideas were articulated with the term 'writer', an analytic step shown by the connections (lines) in red. The whole constitutes a sub-net presenting the social semantic form of the trichotomy 'Writer/ Reader/ World'. This trichotomy may be observed in the image, looking at both the dialectical and hybrid fusion of relationships that are shown in blue and red. Thus, the social natures of the writer and the reader are connected, in multiple ways, to the social world where these subjects work and play as social actors. Some of these social relationships are depicted through Wikipedia discourse, concretely in the Web page 'Magic Realism' in what concerns the particular sociological meanings produced by this artistic/literary movement and by their analyzers in the Wikipedia.

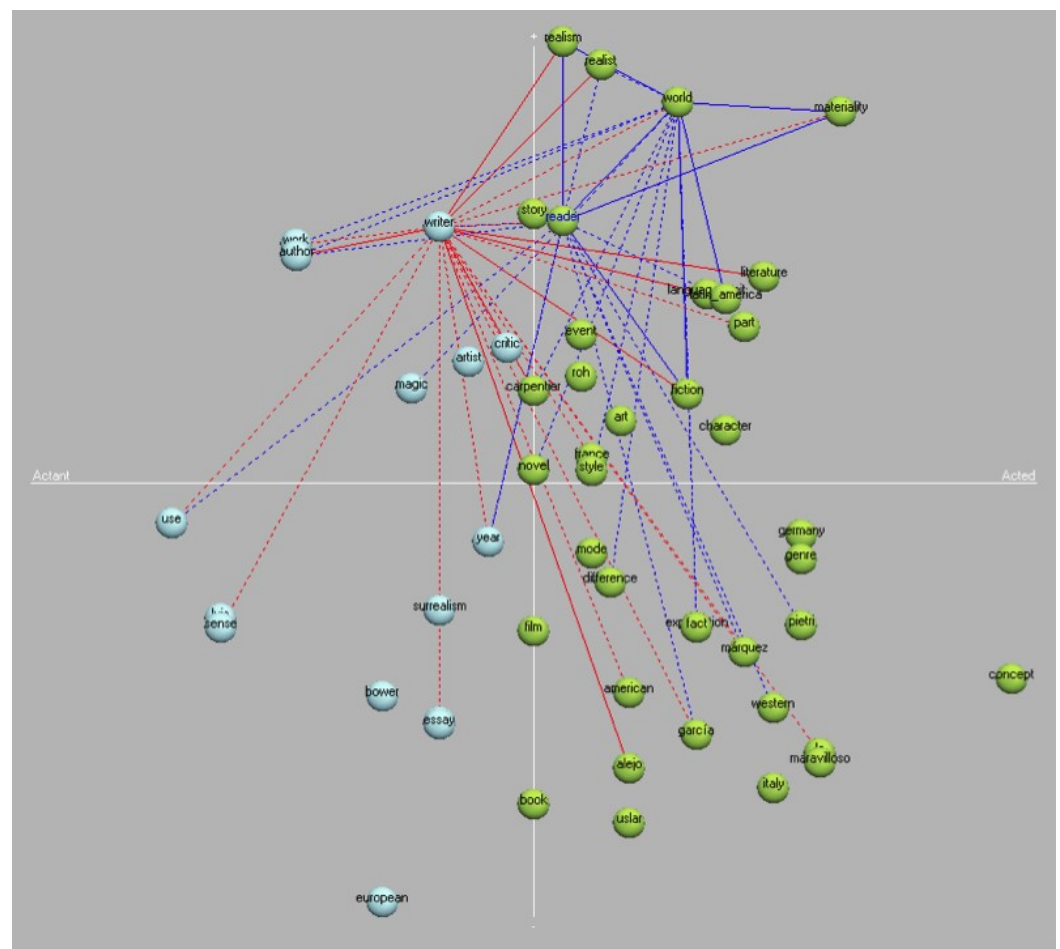

Figure 8. Semantic Logic Network including the trichotomy 'Writer/ Reader/ World'. 


\subsection{Discursive Argumentation and Style}

A written enunciation is not just a static collection of ideas. A rhetorical progression of semantic notions and logical relationships is always present, manifested or implicit. We will analyze the argumentation and style of the Wikipedia article 'Magic Realism' considering both a qualitative and a quantitative approach.

(a) Qualitative perspective

The rhetoric of the text can be observed through the syntactic-semantic indicators in italics within the following sentences included in the article's first page:

"Magic realism is a genre where magic elements are a natural part in an otherwise mundane, realistic environment."

"Although it is used most commonly as a literary genre, magic realism also applies to film and the visual arts."

"On the surface the story has no clear magical attributes."

"but such a character breaks the rules of our real world."

Moreover, the analyzed text, aiming to work as an encyclopedic discourse (Wikipedia's order of discourse), involves mainly an objective 'voice' or 'narrator', who uses often, among other syntactic instruments: (a) verbs in the third person, usually in the present and past tense; and (b) citations from legitimate authorities. For instance:

"Magic realism also applies to film and the visual arts."

"and this is subtly depicted by the character being present throughout many generations."

"The author may give precise details of the real world such as the date of birth of a reference character and the army recruitment age,"

"but such facts help to define an age for the fantastic character of the story that would turn out to be an abnormal occurrence like someone living for two hundred years."

"Professor Matthew Strecher defines magic realism as 'what happens when a highly detailed, realistic setting is invaded by something too strange to believe" ". 


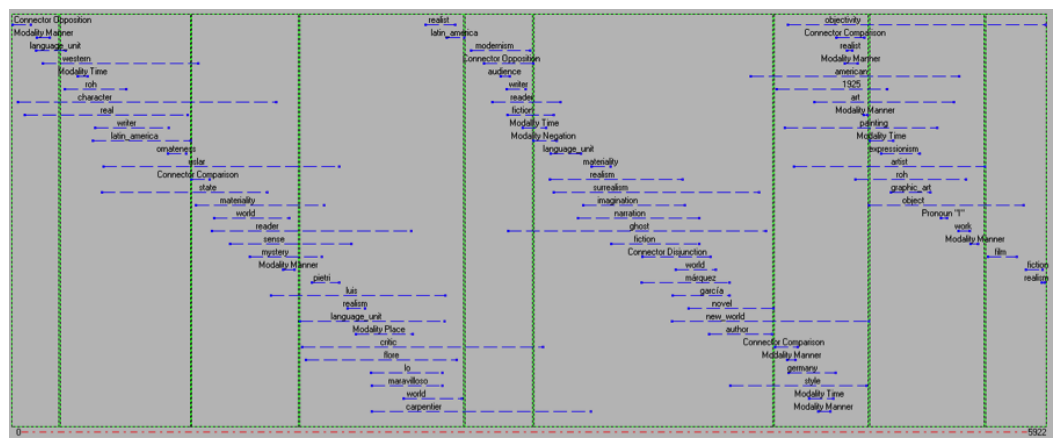

Figure 9. Semantic-logical graph showing concepts and the progression of their argumentative connectors in the article.

Another way of outlining argumentation in a text is extracting semanticargumentative passages showing concepts and their rhetorical connector's progression in the article (see Fig. 9). In this semantic-logical graph, each significant idea is displayed in the form of a horizontal dotted line indicating its extent (length) and its place inside the text. The diachronic argumentative progression is represented on the horizontal axis. Each vertical line signifies a boundary for an episode. This article has 9 semantic-logical episodes, some longer than others. Not just concepts but also Rhetorical Connectors among notions may be observed, like the Connector Opposition, on the left at the beginning of the argumentation, or the Connector Disjunction, at Episode 6.

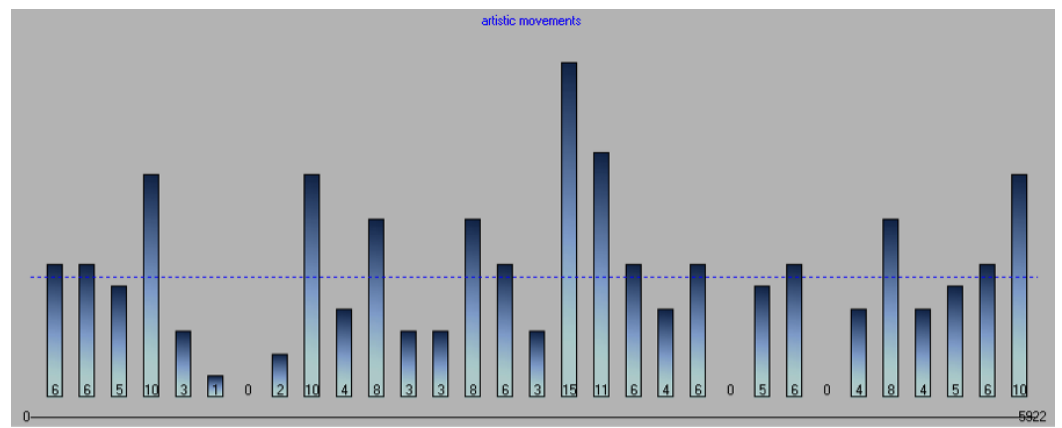

Figure 10. Idea 'Artistic Movements' within the text argumentation strategy (frequencies).

(b) Quantitative approach

Detaching a concept from the totality of the expressed ideas, e.g. 'artistic movements', it is easier to note its diachronic distribution across the article (cf. Fig.10). The size of the histogram bars visually represents the different frequency of this concept within the text's argumentative path. The dotted line indicates the average size of these occurrences. 


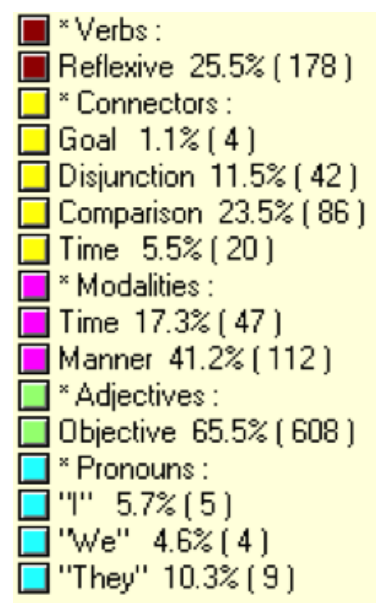

Figure 11. Wikipedia article 'Magic Realism' style, through frequent keywords categories.

It is also possible to conduct an analysis of the frequency and percentages of the main grammatical classes present in the article, and transform them into analytic categories of keywords. Fig 11 is eloquent concerning the discursive style in the article, within the particularities of the written language at Wikipedia. Note that verbs are mainly reflexive (25,5\%). Comparative connectors are the most commonly used by the digital writers of this entry in the encyclopedia (23,5\%). And the main pronoun is 'they' (10,4\%), suggesting an would-be objective narration style. Fig. 12 includes a semantic-logic network showing the (precedent and consequent) concepts connected by reflexive verbs.

\subsection{Hybrid concepts and relation-concepts}

In order to expand the hermeneutical approach inherent to Hybrid Discourse Analysis, a continuous work in progress regarding conceptualization is needed.

\subsubsection{Hybrid concepts}

As for the central ideas contained in this article, they can be translated to what we named bybrid concepts. These may be defined as concepts that articulate and fuse several social dimensions and their meanings, within the defeniendum itself.

A definiendum is the name of the concept that we intend to define. And definiens is the second part of a definition, consisting of words/terms simpler or more known by common sense, or previously defined, which clarify the more 
unknown or complex meanings associated with the concept that is to be defined. In the case of hybrid concepts, notions that help to interpret the meaning of the concept that we need to define, lie at the very heart of this concept's name. For example, the concept 'Magic Realism' (i.e. the definiendum) in a 'classical' definition as we may see in its Wikipedia article, is delimited, among other connotations, using a definiens that includes the following possible more-known words: 'Magic Realism is a genre where magic elements are a natural part in an otherwise mundane, realistic environment.' (see Fig. 4).

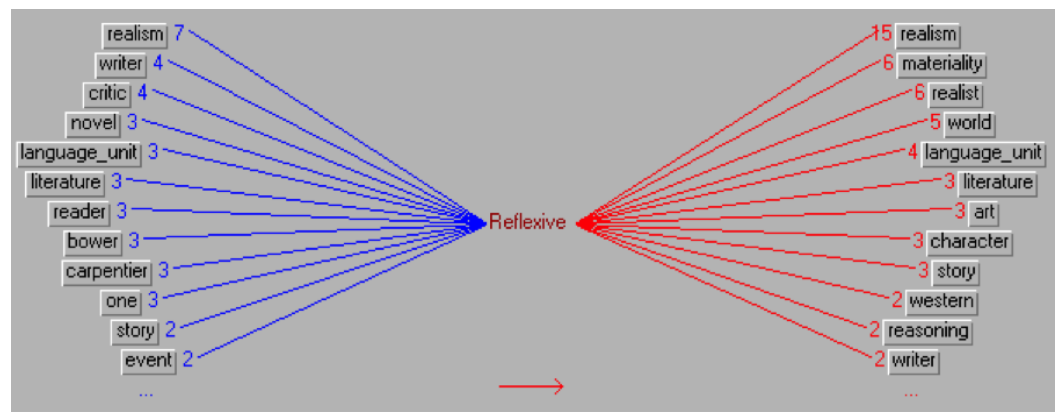

Figure 12. Reflexive verbs and their concepts.

Differently, if one interprets the concept of 'Magic Realism' departing from a definition included in a hybrid hermeneutics (that is to say, as a hybrid concept), we attain the following: the idea of 'Magic Realism' may be understood as a social and discursive process, located somewhere within the hybridization of 2 social dimensions that are used as broader categories of the concept: (a) a 'social processes' dimension and (b) a 'social spheres' dimension. In the intersection of social spheres (economic, political, cultural, etc.) the institutional discourses emerge within a specific social fabric.

Applying these considerations to the concept being defined, the respective notation is 'MAGIC REALISM_p\#d'. (cf. Figs. 13 and 14): The first element, 'Magic Realism' is the idea that you want to circumscribe. The second element, ' $\mathrm{p} \# \mathrm{~d}$ ', separated from the first by an underscore ' - ' is a notation that binds, on one hand, the code associated with a social process, 'p' to, on the other hand, the code connected with discourse, ' $d$ '. The notation '\#' means a relationship between 2 social dimensions. The whole is the hybrid concept that, in this case, articulates the two dimensions here invoked.

\subsubsection{Logical bybrid relations}

As for logical and hybrid relationships, the need for new hermeneutical instruments is even more urgent. We developed earlier an Alphabet of Interconceptual Logical Relations (Andrade, 2007). This alphabet gathers, in a coherent and 
codified whole, relationships extracted from formal logic (Aristotle, Descartes), dialectical logic (Heraclitus, Hegel, Marx), boolean logic used by computers, fuzzy logic associated with artificial intelligence, and even analog logic, which can be found in some systems of non-rational, or irrational or anti-rational thought, such as magic or mythologies.

Note that these logical relationships can be hybridized in several ways. One of these manners is the fusion of the idea 'logical relationship' with the very notion of what we mean by the 'concept' itself. Such fusion, within hybrid hermeneutics and inside HDA, takes the form of the hybrid figure of knowledge named 'relation-concept' (Andrade, 2002). Some examples of these hybrid relations may be observed in Fig. 13, like 'influence ->', 'genealogy $<1$ | $>$ ' and 'hybridization $\mathrm{x}->\&$ '. In other words, such relations don't merely link concepts, as we can find in many network representations, but they have their own relevant position and depiction within a social semantic-logic network. In this way, it is much more straightforward and practical to define the nature of the relationships through their hidden meanings. Furthermore, new types of semantic-logic connections can be discovered, such as:

(a) the ones that link relation-concepts to concepts;

(b) the ones that link relation-concepts to other relation-concepts.

To apply HDA by means of these epistemologically transformed concepts and relationships, the first step is to select socio-semantic fields where the sociologist may undertake his/her analysis and interpretation. In the Wikipedia article analysed, they coincide roughly with the text's main sections. For example, consider the socio-semantic field associated to the text presented earlier in Figure 4.

A possible exegesis of this semantic field's meaning is the one observed in Fig. 13. This semantic-logical network presents the hybrid concept 'MAGIC REALISM' at its left. This is the concept that has more established relationships with others. And this happens through the organization of three semantic-logical subfields, each one having a relation-concept working as a mediating concept, and identified by a specific color.

For example, at the left of the image, take the semantic-logic subfield associated with the relation-concept 'influence ->'. The corresponding original sentence, located within the text of the social semantic field reproduced at Fig.4, is the following: "Although it is most commonly used as a literary genre, magic realism also applies to film and the visual arts."

In the network image, the elements (concepts and relationships) of this subfield are marked through green triangles in the image. The coded relationship '->' expresses the social influence between two phenomena, through the articulation of 2 hybrid concepts: the first is 'MAGIC REALISM', coded 'p\#d', which means 'discursive processus', with ' $\mathrm{p}$ ' meaning 'process' and 'd' meaning 'discourse'. The second concept is 'LITERATURE', coded 'et\#d', that is, 'discursive structure', with 'et' meaning 'structure' (translation of Portuguese word 'estrutura-et') and 'd' meaning 'discourse'. 


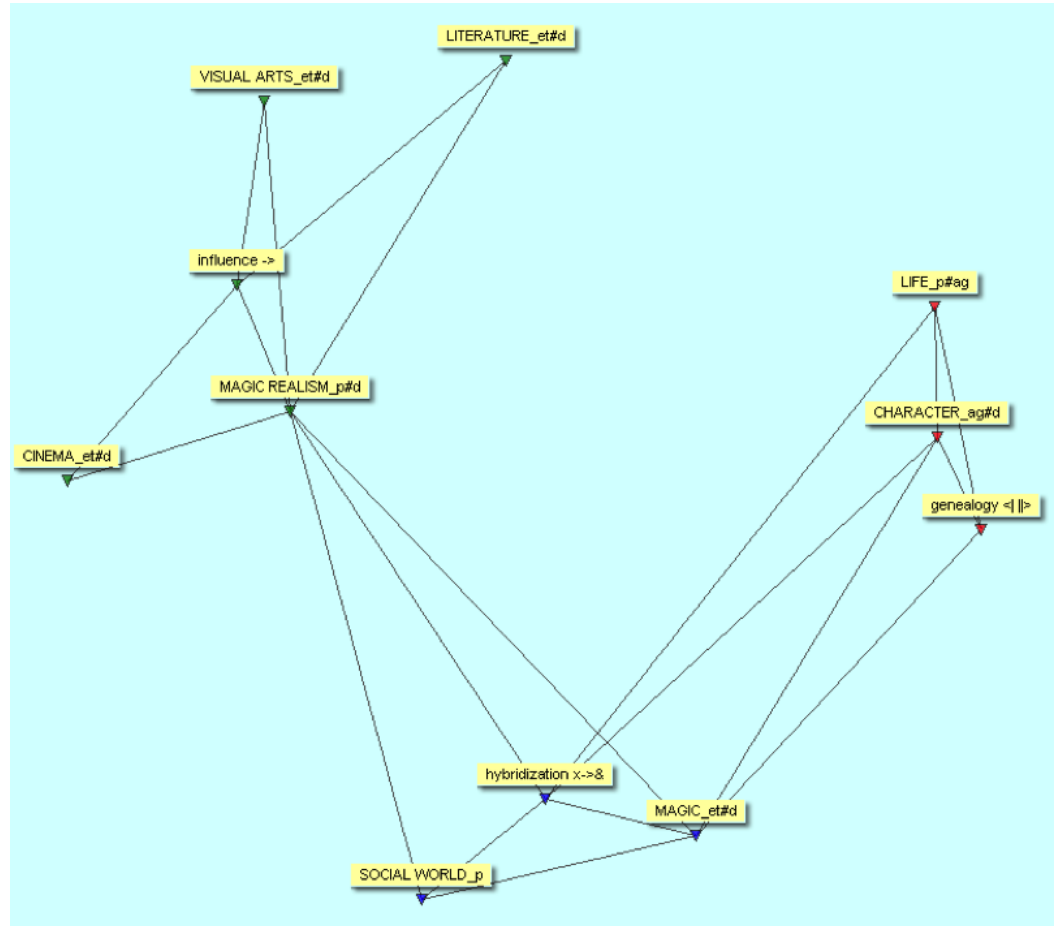

Figure 13. Semantic-logic social network showing concepts and relation-concepts.

The textual sentence that represents a logical proposition in the image expressing this is the following: "Magic Realism influences literature." In order to read such a sentence in the image through its visual notation, the analyst or the reader must go through three steps:

(a) read a precedent concept or concept 1 (in this case, 'MAGIC REALISM_p\#d');

(b) advance across a relation-concept (like 'influence->');

(c) and end this visual reading over a successive concept or concept 2 (such as 'LITERATURE_et\#d').

In the image, it is possible to observe that the same relation (influence>') means the cultural contributions of MAGIC REALISM either for VISUAL ARTS or for CINEMA.

Moreover, other semantic-logical readings are possible within HDA. For instance, the hermeneut may consider that the semantic-syntactic-logical organization of sentences, periods and paragraphs in a text, can be understood not just through pairs of concepts connected by a relationship. This dual arrangement is one of the classical forms of reasoning developed by modernity, in the canonical form 'Concept1/Relation/Concept2', or ' $\mathrm{C} 1 / \mathrm{R} /$ C2'. However, why not cross other semantic-logical roads inside this first sub-network woven around 'influence->', e.g. the paths suggested by the various triangles visible in the image that organize several trichotomies? 


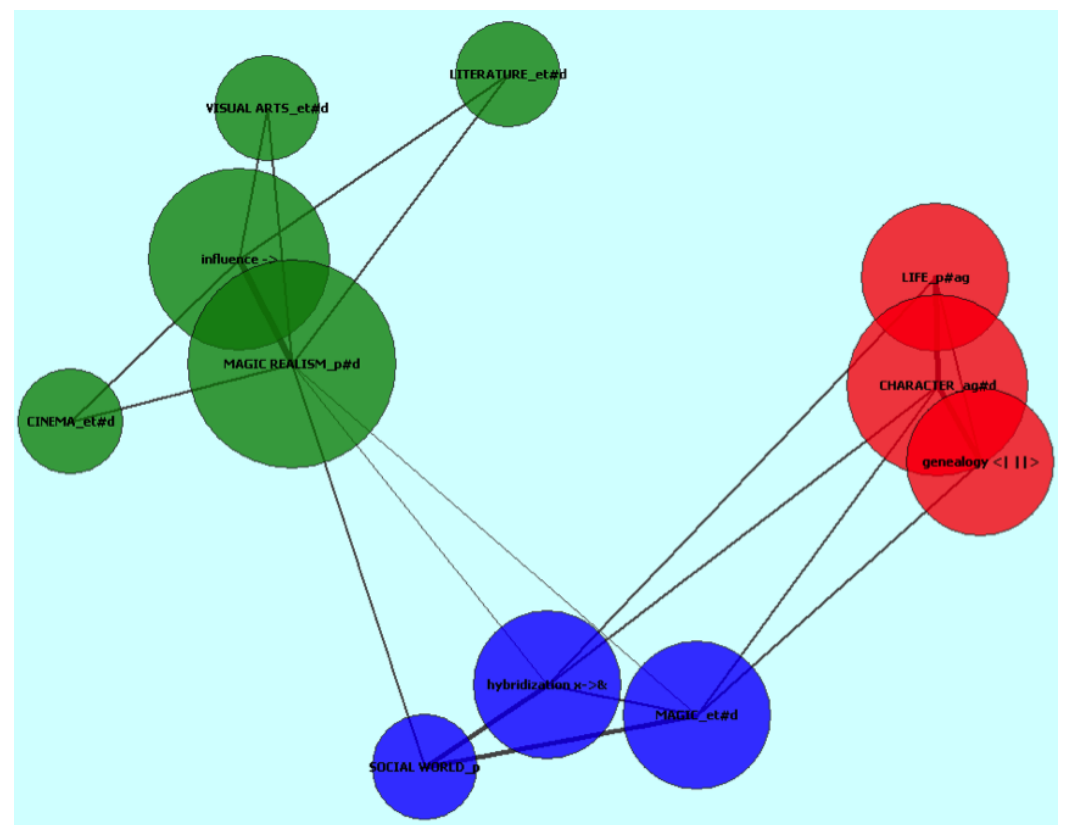

Figure 14. Semantic-logic social network showing semantic intensity.

Please observe now, at the bottom of Fig. 13, the cluster inherent to the semantic subfield associated to the social relationship 'hybridization $\mathrm{x}->\&$ ', shown in blue. ' $x$ ' means negation, '- $>$ ' stands for 'influence'. And the sign ' $\&$ ' has the connotation of mixing 2 entities, each one depicted here by an ' $\mathrm{O}$ ', the upper and the lower 'o' observable within the character ' $\&$ '. Thus, relationships, like concepts, may be hybridized from precedent ones. In this case, '->', a code present, in isolation, inside the relation-concept 'influence- $>$ ', is now one of the elements of relationship ' $\mathrm{x}->\&$ ', which has the synthetic sense of 'hybridization'. Such previous codification of logical relationships was presented in the Alphabet of Interconceptual Relations, in a paper cited above (Andrade, 2007).

The correspondent original and textual meaning found in the Wikipedia article may be summarized by the following sentence: Magic Realism hybridizes, on one hand, magic social structures and, on the other hand, the real world. The path to follow, in the image, to schematize that logical sentence or proposition, is the line that begins in 'Magic Realism', and ends in 'hybridization'. Afterwards, the analyst should cross the triangle 'Hybridization/Social World/Magic', which represents a trichotomy formed by 1 relation-concept and 2 concepts. Such a trichotomy may be enlarged to the broader trichotomy originated by the larger triangle that connects, in the image, 'Magic Realism' to 'Social world' and to 'Magic'.

The third sub-semantic field in Fig. 13 is related to the relationshipconcept 'genealogy', notated as $<\mathrm{I}||>$, and denoted in red. Genealogy means generation (in Greek: genea) of knowledge (logos). Within Michel Fou- 
cault's perspective, meaning can be found not just formally within a statement (énoncé), but mainly considering the sense given by an institutional discourse, which is in close relation with the power that this institution uses to preserve its legitimacy. And this power relates with a discontinuous diachrony, or épistemè (Foucault, 1982; Mahon, 1992). Within Magic Realism, the Western genealogy of power is hybridized with other ones, originated in nonWestern cultures. This cultural creolization blending a rationalized human life and a magical human life, which has multi/inter/transcultural genealogic roots, may be observed in some detail in the second and third paragraphs of the social semantic field shown in Fig. 4.

Furthermore, Hybrid Discourse Analysis fuses/blends qualitative and quantitative methodologies. This hybridization is also visible in Fig. 14, which illustrates the operational hybrid concept named 'semantic intensity'. On one hand, such a semantic intensity works empirically, in a corpus of sources, through the semic power of each concept, which is visible in a given network, through a visual detail. For example, 'MAGIC REALISM_p\#d' is the semantically strongest hybrid concept, inside the analyzed Wikipedia page. This dominance is expressed formally by the larger circle in the image at Fig.14. On the other hand, the most semantically intense inter-conceptual relations-concepts are represented by the larger lines, placed on the lower right-hand side of the image.

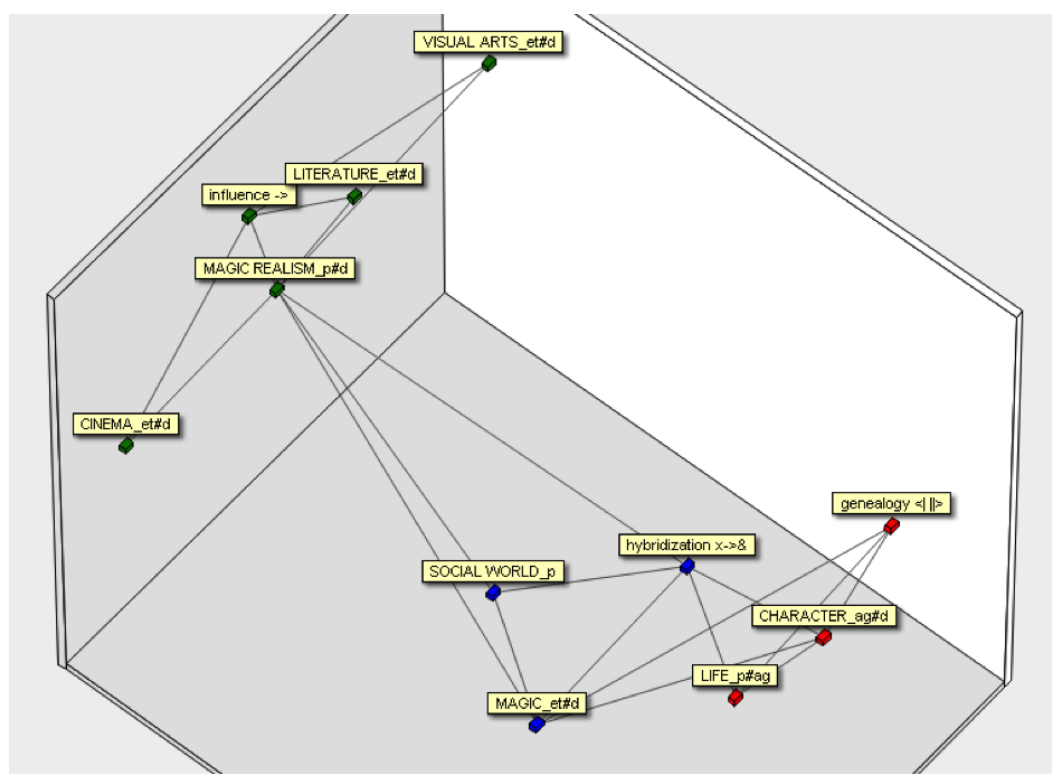

Figure 15. Semantic-logic social network in 3D.

Figure 15 also shows the semantic-logic network that represents the social semantic field visible in Fig. 4, but this time exhibited through 3D space. Within the process of applying such $3 \mathrm{D}$ graphics to a rich media presentation 
or to an educational game, various angles/perspectives of this semanticlogical network may be underlined to users (students, researchers, etc.).

Another data visualization showing hybridization between quantitative and qualitative methods can be seen in Fig. 16. This dendogram presents, on the right, the qualitative relationships of agglomeration among the concepts and the relationships concerned. Note that the first 2 sub-fields are derived (see the dotted lines) from the 3rd sub-field, the one structured around the relation 'influence'. And at the same time, on the graph's left, it is possible to see, through the horizontal bars, the quantitative proportional values of the various concepts and relations' occurrences, mentioned in the text of this article's first semantic field. The analysis shows that the concept 'Magic Realism' and the relation 'influence', marked in green, are the poles most frequently related, within this semantic-logical social network. Thus, we may say that the sub-field organized around these 2 semantic-logical elements, is also the most prominent quantitatively.

Finally, notice that 'hybridization' appears as a meta-bybrid relationship, in the sense that it mediates the 2 clusters defined by the 2 relations 'influence' and 'genealogy'.

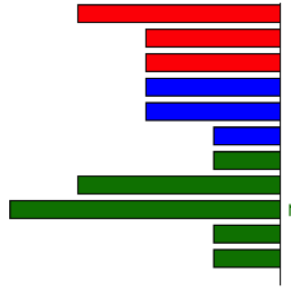

Figure 16. Dendogram of the article's first semantic field.

\section{Conclusion}

Within our globalized, post-colonial and multi/inter/transcultural planet, hybridizations are occurring in multiple social realms. Such processes must be interpreted through original theories and methodologies, in which 'original' may be perceived both in the sense of 'seminal' and 'innovative'. Hybrid Analysis of Discourse (HDA) tries to move in this direction, but does so while considering this research commitment to be a long work in progress. The main goals are to approach sociological objects of study under different socio-cultural perspectives, and hopefully involve more and more common people as lay researchers, within our research society. The experimentation with new media, such as hypermedia and/or hybrimedia, for sociological research, is another major goal. Subscribing to an open research, this approach may contribute to an open memory of the contemporary that can 
inform the eye and touch of the sociologist, who, like all other social actors, is nowadays inevitably a social and cultural hybrid.

\section{References}

ANDRADE, Pedro, ed. (2016). Comunicação Pública da Arte: O Caso dos Museus de Arte Locais/Globais. Lisboa: Edições Caleidoscópio.

ANDRADE, Pedro, Carlos Almeida Marques, and José Cunha Barros, eds. (2010). Arte Pública e Cidadania: Novas Leituras na Cidade Criativa. Lisboa: Edições Caleidoscópio.

ANDRADE, Pedro (2014). "Post-Colonial Co-Ordinary Literature and the Web 2.0/3.0: Thinking Back within Transmediatic Knowledge." New Literary Hybrids in the Age of Multimedia Expression: Crossing Borders, Crossing Genres. Ed. Marcel Cornis-Pope. Amsterdam: John Benjamins. 123-144. doi: 10.1075/chlel.xxvii.08and.

(2011). Social Semantic Sites:

"Public Communication of Art." n.d. 28 May 2016.

https:// sites.google.com/site/compubartenglish/.

“Wars for Peace." n.d. 28 May 2016.

https://sites.google.com/site/peacewarsenglish.

“Experimental Books." n.d. 28 May 2016.

https://sites.google.com/site/livrosexperimentaisenglish/.

“Web 3 Novel." n.d. 28 May 2016.

https://sites.google.com/site/web3novelenglish/.

(2011a). Sociologia Semântico-Lógica da Web 2.0/3.0 na Sociedade da

Investigação: Significados e Discursos Quotidianos em Blogs, Wikis, Mundos/Museus Virtuais e Redes Sociais Semântico-lógicas. Lisboa: Edições Caleidoscópio.

(2011b). Novas Autorias / Leitorias / Actorias: Escrita Comum, Literacias Hibridas e Anti-vigilancias na Web 2.0. Lisboa: Edições Caleidoscópio.

(2011c). Novela GeoNeológica n 1: Um Caso de Literatura Transmediática, Primeira Novela da Web 3.0. Lisboa: Edições Caleidoscópio.

ed. (2010b). Museus, Públicos e Literacia Cientifico-Tecnológica: Redes

Sociais de Comunicação de Significados no Espaço Interdimensional do Museu. Lisboa: Edições Colibri.

(2008). “A sociedade da investigação e do jornalismo: boas práticas de cidadania participativa através da internet móvel e do social bookmarking." Anuário Internacional de Comunicação Lusófona. SOPCOM. 307-312.

(2007). "O Alfabeto de Relações Universais." Revista de Comunicação e Linguagens 38: 143-155.

(2002). "Some synthetic ideas to work with qualitative analysis." Atalaia/Intermundos 10/11: 153-165. 
BAKHTIN, Mikhail (1985). The Dialogic Imagination: Four Essays. Austin, Texas: University of Texas Press.

CANCLINI, Nestor (2005). Hybrid Cultures: Strategies for Entering and Leaving Modernity. Minneapolis: University of Minnesota Press.

CARROLL, Brian (2014). Writing and Editing for Digital Media. New York: Routledge.

CASTELLS, Manuel (2000) The Rise of the Network Society. Oxford: WileyBlackwell.

CRIMP, Douglas, and Louise Lawler (1995). On The Museum's Ruins. Cambridge, Massachusetts: The MIT Press.

FOUCAULT, Michel (1982). The Archaeology of Knowledge \& The Discourse on Language. New York: Vintage.

GEE, James, Michael Hanford (2013). The Routledge Handbook of Discourse Analysis. New York: Routledge.

HANSON, Valerie (2015). Haptic Visions: Rhetorics of the Digital Image, Information and Nanotechnology. Anderson, SC: Parlor Press.

HOOVER, David, and Jonathan Culpeper (2014). Digital Literary Studies: Corpus Approaches to Poetry, Prose and Drama. New York: Routledge.

JONES, Rodney, Alice Chik, and Christoph Hafner, eds. (2015). Discourse and Digital Practices: Doing Discourse Analysis in the Digital Age. New York: Routledge.

LEAVY, Patricia (2009). Method Meets Art: Arts-Based Research Practice. New York: The Guilford Press.

“Magic Realism.” (2012). Wikipedia. 20 Dec. 2012. 28 May 2016. http:/ / en.wikipedia.org/wiki/Magic Realism.

MAHON, Michael (1992). Foucault's Nietaschean Genealogy: Truth, Power, and the Subject. New York: State University of New York Press.

MARQUEZ, Gabriel Garcia (2006). One Hundred Years of Solitude. New York: Harper Perennial Modern Classics.

PAGE, Ruth (2011). New Narratives: Stories and Storytelling in the Digital Age. Lincoln: University of Nebraska Press.

TAGG, Caroline (2015). Exploring Digital Communication: Language in Action. New York: Routledge.

TANNEN, Deborah, and Anna Trester (2013). Discourse 2.0: Language and New Media. Washington, DC: Georgetown University Press.

THURLOW, Crispin, and Kristine Mroczek (2011). Digital Discourse: Language in the New Media. Oxford: Oxford University Press.

(C) 2016 Pedro Andrade. Licensed under the Creative Commons Attribution-NoncommercialNo Derivative Works 4.0 International (CC BY-NC-ND 4.0). 